\title{
ADAPTASI MASYARAKAT NELAYAN TERHADAP KERENTANAN FISIK PESISIR PULAU BINTAN
}

\author{
Helfinalis $^{\mathrm{a}, *}$, Yunia Witasari ${ }^{\mathrm{a},}$, Singgih Prasetyo ${ }^{\mathrm{a}}$ \\ aPusat Penelitian Oseanografi LIPI, Jl. Pasir Putih 1, Ancol Jakarta Indonesia \\ *Koresponden penulis (1) : irasatwain@gmail.com (2)finalis55@yahoo.com
}

\begin{abstract}
Abstrak
Pulau Bintan adalah pulau yang secara geografis posisinya menghadap laut cina selatan, sangat dipengaruhi oleh faktor meteorologi dan oseanografi, memiliki intensitas pelapukan di daratan yang tinggi karena cuaca dan iklim yang ekstrim. Perubahan garis pantai yang dinamis dan kegiatan manusia yang makin meningkat juga akan berdampak terhadap tingkat kerentanan fisik wilayah pantai dan imbasnya adalah masyarakat nelayan. Tujuan penelitian ini untuk mengetahui seberapa besar dampak perubahan tersebut terhadap sosial ekonomi masyarakat nelayan Pulau Bintan.Aspek penelitian berdasarkan data meteorologi, pasang surut, turbiditas, elevasi kawasan pantai, statistik demografi dan kronologi sedimentasi. Analisis tiungkat kerentanan mengacu pada metode CVI (Coastal Vunerability Index) dan SIDIK (Sistem Informasi data Indeks Kerentanan). Hasil pembobotan skor diperoleh bahwa lingkungan fisik Bintan sebelah timur tergolong rendah sampai sedang. Kerentanan masyarakat pesisir tergolong rendah di kawasan wisata, namun tinggi di kawasan perikanan. Tingginya kerentanan masyarakat pesisir di kawasan perikanan lebih dipengaruhi faktor sosial dan budaya dibandingkan faktor alam/iklim. Strategi adaptasi yang tepat adalah strategi akomodatif, dimana masyarakat tetap beraktifitras di kawasan ini dengan adaptif dalam memaksimalkan fungsi lahan.
\end{abstract}

Kata Kunci: Kerentanan Lingkungan Fisik, masyarakat pesisir, perubahan iklim, Bintan

\begin{abstract}
Bintan Island is an island geographically facing the South China Sea, highly influenced by meteorological and oceanographic factors, and has a high intensity of weathering on land due to extreme weather and climate. Changes in the dynamic coastline and increasing human activities will also have an impact on the level of physical vulnerability of the coastal area and the impact is the fishing community. The purpose of this study was to determine how much the impact of these changes on the socioeconomic impact of the fishing community of Bintan Island. The research aspects were based on meteorological data, tides, turbidity, elevation of coastal areas, demographic statistics and sedimentation chronology. Vulnerability level analysis refers to the CVI (Coastal Vunerability Index) and SIDIK (Vulnerability Index Data Information System) methods. The results of the weighting of the scores show that the physical environment of eastern Bintan is low to moderate. The vulnerability of coastal communities is low in tourist areas, but high in fisheries. The high vulnerability of coastal communities in fisheries areas is more influenced by social and cultural factors than natural / climatic factors. The right adaptation strategy is an accommodative strategy, in which the community continues to be active in this area adaptively in maximizing land use.
\end{abstract}

Keywords: Physical Environmental Vulnerability, coastal communities, climate change, Bintan

\section{PENDAHULUAN}

Pulau Bintan sebagai salah satu pulau kecil yang secara geografis posisinya menghadap Laut Cina Selatan, sangat dipengaruhi oleh faktor meteorologi dan oseanografi. Selain itu, intensitas pelapukan di daratan Pulau Bintan yang tinggi karena cuaca dan iklim yang ekstrim telah terjadi sejak jutaan tahun menyebabkan perubahan topografi pesisir. Perubahan garis pantai yang dinamis juga kerap terjadi di daerah kepulauan yang terletak menghadap laut lepas atau samudera. Faktor kegiatan manusia yang makin meningkat juga tidak bisa diabaikan, seperti penambangan bauksit, pasir laut, 
konversi dan alih fungsi lahan di daratan. Kegiatan pembukaan lahan selain diperuntukan sebagai perkebunan juga pembangunan fisik seperti perumahan, pertokoan dan fasilitas umum sebagai konsekuensi untuk meningkatkan pertumbuhan ekonomi daerah. Dalam upaya pengelolaan wilayah pesisir di Bintan Timur yang dimulai dari hulu sampai hilir perlu dilakukan dengan mempertimbangkan berbagai aspek seperti fisika, biologi, kimia dan sosial masyarakat.

Faktor alami seperti perubahan curah hujan, suhu, angin, pasang surut, dekomposisi batuan, digabungkan dengan faktor kegiatan manusia di Pulau Bintan mengindikasikan kerentanan lingkungan fisik kawasan pesisir (sedimentasi, erosi, penurunan kualitas tanah).Kerentanan ini akan memberi dampak kerugian dari perubahan iklim yang mungkin akan terjadi terhadap kelangsungan kawasan wisata bahari dan mata pencarian masyarakat nelayan tradisional di Pulau Bintan. Obyek wisata utama di Bintan saat ini adalah Bintan Resorts, destinasi pantai yang spektakuler di utara dan timur pulau, yang meliputi 23.000 hektar di sepanjang pantai berpasir putih yang menghadap Laut Cina Selatan [3]. Seberapa besar tingkat kerentanan tergantung dari kondisi alam dan adaptasi alami lingkungan yang berbeda-beda tiap daerah.

Pantai timur dan utara Pulau Bintan secara geografis berhadapan langsung dengan Laut Cina Selatan yang dimanfaatkan sebagai kawasan wisata bahari. Selama tahun 20052014 telah terjadi abrasi maupun sedimentasi pada beberapa lokasi di sepanjang pantai timur Pulau Bintan. Pembangunan infrastruktur penunjang kegiatan wisata seperti hotel dan resort diduga memberikan pengaruh terhadap proses perubahan garis pantai timur Pulau Bintan [4]

Kerentanan wilayah pesisir merupakan kondisi dimana terdapat peningkatan proses kerusakan di wilayah pesisir yang diakibatkan oleh berbagai faktor seperti aktivitas manusia dan faktor alami seperti pengaruh kenaikan muka laut, gelombang laut serta arus menyusur pantai yang mengakibatkan terjadinya proses abrasi maupun sedimentasi yang merupakan salah satu indikator adanya tekanan terhadap suatu kawasan pesisir. Wilayah pesisir semakin menghadapi tekanan tinggi dari aktivitas alami dinamika pesisir termasuk angin dan gelombang yang berdampak pada dinamika bentang lahan [1];[2]. Sementara menurut [7] kerentanan pesisir merupakan suatu kondisi yang menggambarkan keadaan yang mudah mendapatkan pengaruh (susceptibility) dari faktor alami maupun faktor aktivitas manusia.

[6] mendefinisikan kerentanan sebagai suatu faktor resiko internal dari objek atau sistem yang terekspos suatu bahaya sehubungan dengan kecenderungannya yang mudah dipengaruhi atau rentan terhadap kerusakan.

Analisis kerentanan pesisir sangat penting untuk dilakukan dengan melakukan kajian kondisi suatu kawasan pesisir khususnya kajian mengenai kerentanan suatu kawasan pantai wisata, karena akan memudahkan dalam menyoroti pengaruh dari kerentanan kawasan pantai tersebut terhadap kawasan lingkungan fisik pesisir pada umumnya, dan dampaknya terhadap sosial ekonomi masyarakat pesisir. Tujuan penelitian ini adalah Mengetahui perubahan fisik wilayah pesisir khususnya kawasan nelayan, dan adaptasi yang diperlukan oleh komunitas nelayan dalam menghadapi kerentanan fisik wilayah pesisir

\section{METODE}

Penelitian ini dilaksanakan di Pesisir Timur dan Utara Pulau Bintan (Gambar 1) di Kecamatan Gunung Kijang, Kecamatan Teluk Bintan, Kecamatan Teluk Sebong, dan Kecamatan Bintan Timur pada 5-13 April 2017. Pengukuran topografi pantai terhadap muka laut rata-rata menggunakan teodolite. Pengambilan sampel sedimen dilakukan di 3 daerah yaitu Sungai Kawal, Galang Batang dan Sungai Tanjung Berakit. Sedimen diambil dengan metode core dengan tangan dan pipa pralon setebal maksimal 1 meter dari permukaan. 


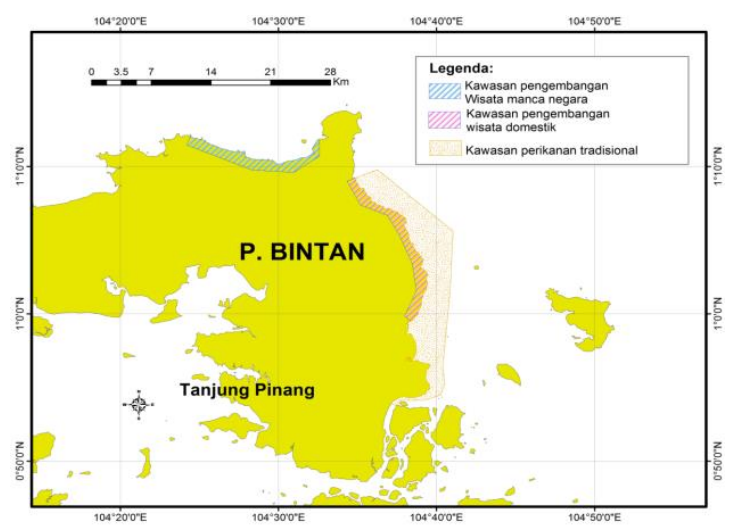

Gambar 1. Lokasi pengambilan data lapangan

Analisis tingkat kerentanan pantai menggunakan metode coastal vulnerability index (CVI) berdasarkan bobot dan skor variabel yang ditetapkan oleh United States Geological Survey (USGS) dan disesuaikan dengan area kajian untuk menentukan nilai CVI mengacu pada [9].

$$
\text { CVI }=\sqrt{ } a * b * c * d * e / n
$$

$\mathrm{a} \quad=$ Variabel geomorfologi pantai

$\mathrm{b}=$ Variabel abrasi/sedimentasi

c $=$ Variabel kemiringan pantai

$\mathrm{d}=$ Variabel rata-rata tinggi gelombang

$\mathrm{e}=$ Variabel tidal range

$\mathrm{n} \quad=$ Jumlah variabel

$\mathrm{CVI}=$ Coastal vulnerability index .

\section{HASIL DAN PEMBAHASAN}

\section{Lingkungan Fisik Pesisir terhadap Perubahan Iklim}

Dampak perubahan iklim di pulau kecil secara fisik dipengaruhi oleh geomorfologi wilayah pesisir, yang merupakan suatu sistem komplek dengan perubahan dan dinamika yang tinggi, sebagai respon terhadap berbagai hal terkait dengan kejadian cuaca yang ekstrim [2]. Tiap kawasan pesisir berbeda karakteristik lingkungan dan potensi sumber daya alamnya sehingga kajian dampak perubahan iklim harus dikaitkan dengan aspek fisik strategis di kawasan tersebut.

Aspek fisik yang secara langsung berkaitan dengan perubahan iklim ekstrim yaitu

(1). Geomorfologi pantai, (2) Ketinggian Permukaan Tanah, (3) Tunggang pasut rata- rata, (4) Tinggi Gelombang Signifikan, (5) Kenaikan Muka Air Laut Relatif, (6) Perubahan Garis Pantai, (7) Penggunaan Lahan, (8) Litologi, (9) Luas Kerusakan Pantai, (10) Lebar sabuk hijau merupakan modifikasi dari persamaan umum penentuan indeks kerentanan pantai [8]; [9]; [10].

\section{Geomorfologi}

Geomorfologi pantai di Indonesia umumnya bervariasi, karena posisi Indonesia yang terletak diantara 3 lempeng tektonik yang aktif, dilalui oleh jalur vulkanik, dikelilingi 2 samudra sehingga dipengaruhi faktor oseanografi dan meteorologi. Indonesia bagian barat umumnya memiliki bentuk geomorfologi lebih sederhana dibandingkan dengan Indonesia bagian Timur. Konfigurasi tektonik yang membentuk morfologi Indonesia bagian Barat berada dalam kerangka kerak benua Asia, yaitu kontinen Sunda (Paparan Sunda), sedangkan Indonesia bagian Timur berada dalam kerangka kerak samudra Pasifik dan mikro kontinen Filipina.

\section{Geomorfologi Pulau Bintan}

Secara geografis posisi Pulau Bintan sebelah utara dan timur menghadap Laut Cina Selatan, sehingga dipengaruhi oleh faktor meteorologi dan oseanografi. Pembentukan geomorfologi pesisir saat ini juga dipengaruhi intensitas pelapukan batuan di daratan yang tinggi. Satuan geomorfologi adalah bentukan dalam bagian kecil dan memiliki karakteristik fisik dan proses dinamis yang berbeda pada tiap daerah dibandingkan dengan bentuk morfologi regional. Secara umum, Pulau Bintan adalah berupa dataran alluvial yang landai perbukitan bergelombang lemah. Bentang alam pantai yang relative landai, akan berpengaruh pada kerentanan fisik di pesisir, diperlihatkan dalam sketsa dibawah ini (Gambar 2) 


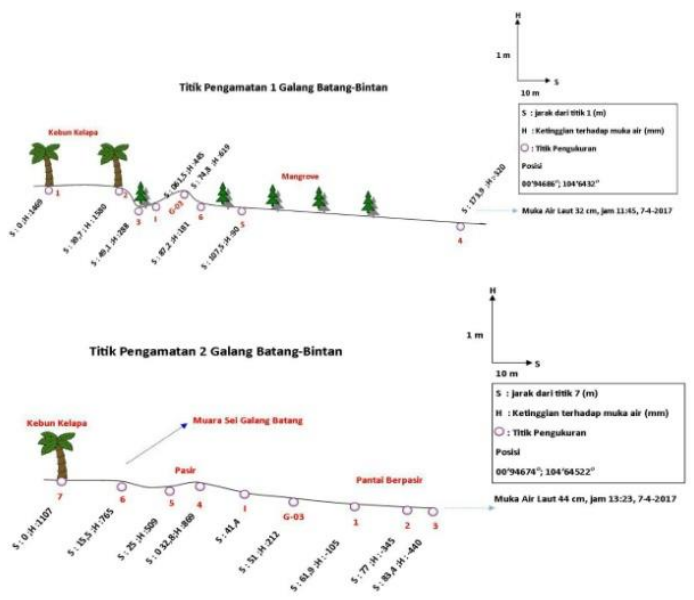

Gambar 2. Profil elevasi pantai Galang Batang [3]

\section{Tipe Pantai di Pulau Bintan}

Pantai timur Pulau Bintan merupakan pantai berpasir dan berbatu dengan panjang garis pantai $29.10 \mathrm{~km}$. Pantai timur Pulau Bintan merupakan pantai yang landai dengan tingkat kemiringan pantai pada jarak 0-1 km dari garis pantai berkisar antara $0.09-0.16^{\circ}$ (0.16-0.28\%).

Daerah pantai berdasarkan morfologinya, daerah pantai di kelompokkan ke dalam 4 macam, yaitu:

a. Pantai berbatu dan bertebing terjal (cliff)

b. Pantai berpasir dan bergisik

c. Pantai berawa payau/mangrove

d. Pantai berterumbu karang.

\section{Pantai bertebing terjal (cliff)}

Bentukan dan roman cliff berbeda satu dengan yang lainnya, karena dipengaruhi oleh struktur batuan, dan jenis batuan serta sifat batuan. Aktivitas pasang surut dan gelombang mengikis bagian tebing, sehingga membentuk bekas-bekas abrasi seperti:

a. Tebing (cliff)

b. Tebing bergantung (notch)

c. Rataan gelombang pasang surut

Tebing pada batuan beku akan lain dengan tebing pada batuan sedimen. Pelapisan batuan sedimen misalnya akan berbeda dengan pelapisan yang miring dan pelapisan mendatar.

Pada daerah bertebing terjal, pantai biasanya berbatu (rocky beach) berkelokkelok dengan banyak bentukan gerak massa batuan (mass movement rockfall type). Proses ini mnyebabkan tebing bergerak mundur (slope retreat) khususnya pada pantai yang proses abrasinya aktif.

Contoh di Pantai Trikora/Gunung Kijang. Rataan gelombang pasang surut pada pantai bertebing terjal ini merupakan suatu zona yang tekadang terendam air laut pada saat pasang naik dan terkadang kering pada saat air laut surut.

Rataan gelombang pasang surut ini sering juga merupakan beach dengan meterial dengan sortasi beragam berupa material halus sampai kasar yang tergangtung pada kekuatan gelombang yang bekerja pada pantai. Untuk memperjelas tentang pantai terbing terjal tersebut dapat dilihat pada Gambar 3.

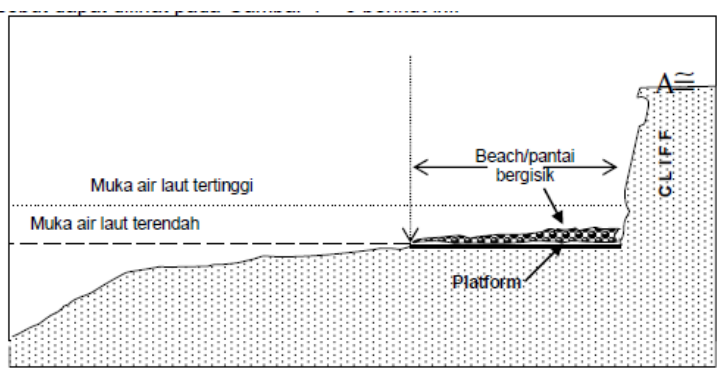

Gambar 3. Gambaran Pantai Bertebing [3]

Tipe pantai di Bintan timur contohnya di Pantai Trikora umumnya merupakan pantai berpasir, terdiri dari material hasil pelapukan batuan granitoid. dengan kemiringan lereng pantai kurang lebih $6^{\circ}$ dan lebar sekitar $15 \mathrm{~m}$ sedangkan di pantai Kawal berupa pasir halus hingga kasar yang bercampur dengan lanau. dengan terdapat sedikit tumbuhan mangrove (Gambar 4)

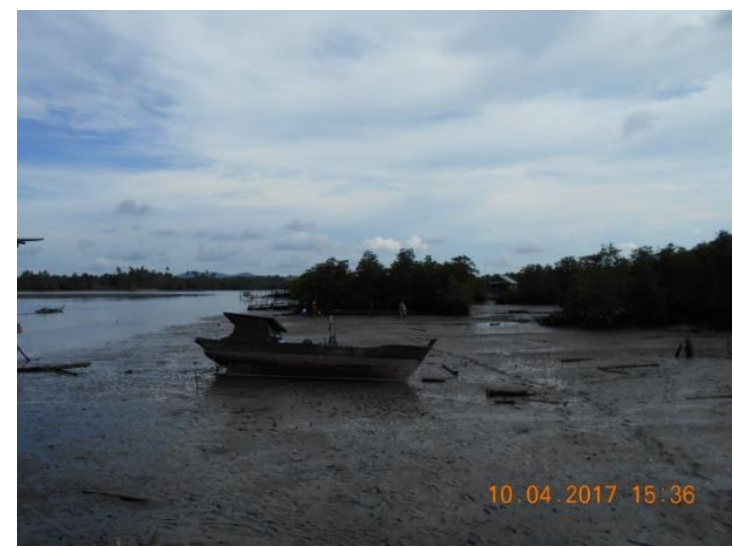

Gambar 4. Pantai pasir dengan mangrove di Kawal, sebelah tenggara Pulau Bintan [3] 
Batimetri dasar laut di sekitar pantai termasuk landai dengan kedalaman berkisar 032 meter (Gambar 5)

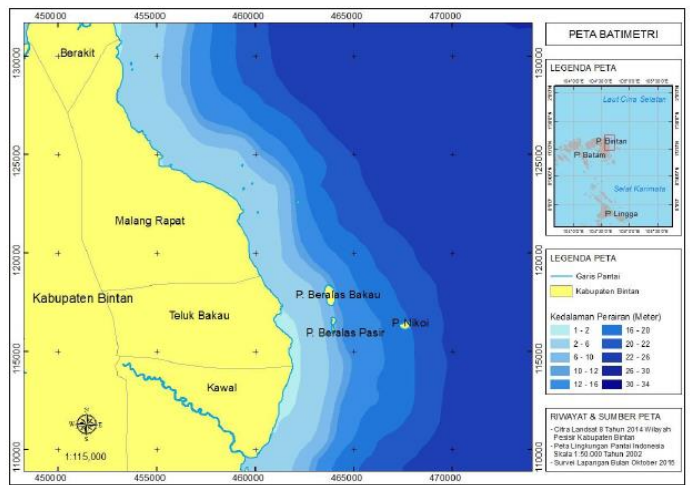

Gambar 5. Batimetri Pantai Timur Pulau Bintan [4]

\section{Litologi}

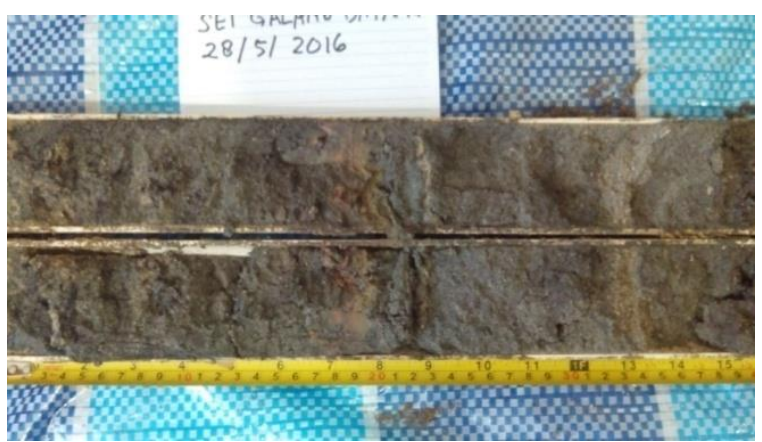

Gambar 6. Litologi sedimen pantai Pulau Bintan sebelah Timur [3]

Dari kenampakan litologi yang diambil secara vertikal, memperlihatkan perubahan jenis litologi yang ditunjukkan dengan adanya lapisan-lapisan laterit, endapan alluvial sungai, dan endapan laut yang silih berganti. Lapisan endapan laterit terbentuk oleh batuan yang mengandung alumina dan adanya proses pelapukan fisik yang intensif. Endapan alluvial sungai ditunjukkan dengan sedimen dari hasil rombakan batuan beku, batuan sedimen. Batuan sedimen terdiri dari sedimen hasil pelapukan batuan sedimen vulkanik, batu pasir, fragmental batuan andesit, tuff dan diorite. Pada lapisan permukaan ditutupi lapisan lempung berwarna kemerahan yang terdiri dari laterit dan limonit. Di lapisan bawah permukaan terdapat sisipan lempung berwarna coklat kemerahan.dan serasah tumbuhan. Sedangkan endapan laut dicirikan dengan adanya kandungan detritus biota laut seperti cangkang moluska, foraminifera, batuan gampingan dan pecahan batuan laut dalam seperti rijang dan galukonit. contoh litologi di daerah pantai diperlihatkan di Gambar 6. Karakteristik litologi Bintan mencirikan bahwa tingakat pelapukan tinggi terjadi karena komposisi alumina yang terdapat dalam endapan bauksit sangat mudah teroksidasi dan mengalami pelapukan kimia, serta kondisi iklim sangat mempengaruhi pelapukan fisik.

\section{Kerentanan Fisik Pesisir}

Kerentanan didefinisikan sebagai suatu faktor resiko internal dari objek atau sistem yang terekspos suatu bahaya sehubungan dengan kecenderungannya yang mudah dipengaruhi atau rentan terhadap kerusakan. Menurut [7] kerentanan pantai merupakan suatu kondisi yang menggambarkan keadaan yang mudah mendapatkan pengaruh (susceptibility) dari faktor alami maupun faktor aktivitas manusia. Faktor-faktor alami yang dapat mempengaruhi tingkat kerentanan suatu pantai yaitu geomorfologi pantai, pasang surut, tinggi gelombang laut, kemiringan pantai serta proses perubahan garis pantai yang ditunjukan oleh fenomena abrasi dan sedimentasi [8]; [9.]

Pantai timur Pulau Bintan secara geografis berhadapan langsung dengan Laut Cina Selatan yang dimanfaatkan sebagai kawasan wisata pantai serta wilayah konservasi padang lamun. Selama tahun 20052014 telah terjadi abrasi maupun sedimentasi pada beberapa lokasi di sepanjang pantai timur Pulau Bintan. Pembangunan infrastruktur penunjang kegiatan wisata seperti hotel dan resort diduga memberikan pengaruh terhadap proses perubahan garis pantai timur Pulau Bintan.

Data yang telah diperoleh berupa data fisika, kimia, meterologi, dan geologi, yang digabungkan dengan hasil penelitian [5] dapat digunakan sebagai landasan membuat suatu indeks dan peta kerentanan wilayah pesisir. Indeks dan peta inibisa digunakan oleh pemerintah daerah setempat dalam pengelolaan sumber daya alam pesisir dan meningkatkan antisipasi terhadap bencana di kawasan pesisir yang kemungkinan terjadi. 
Analisis tingkat kerentanan pantai dan pesisir mengacu pada metode CVI (Coastal Vunerability Indeks) dan SIDIK (Sistem Informasi data indeks kerentanan) berdasarkan bobot dan skor variable yang ditetapkan oleh USGS dan disesuaikan dengan area kajian (Tabel 1 dan Gambar 7). Hasil dari pembobotan skor diperoleh bahwa skor kerentanan lingkungan fisik kawasan wisata di Desa Teluk Bakau, Pantai Trikora, Desa Malang Rapat tergolong kategori kerentanan sedang. Sedangkan Desa Berakit, Tanjung Kaling dan Galang Batang tergolong kerentanan rendah. Faktor kerentanan pesisir lebih dipengaruhi oleh faktor geomorfologi dan sifat fisik sedimen, sedangkan faktor oseanografi hanya berpengaruh besar pada puncakperalihan musim.

Tabel 1. Nilai Kerentanan fisik di daerah penelitian Pantai Bintan

\begin{tabular}{|l|c|c|c|c|c|c|c|c|}
\hline \multicolumn{1}{|c|}{ Lokasi } & \multicolumn{7}{|c|}{ Skor CVI } & Kategori \\
\cline { 2 - 8 } & KP & TG & PS & TP & AS & AP & $\begin{array}{c}\text { Nilai rata- } \\
\text { rata }\end{array}$ & Kerentanan \\
\hline $\begin{array}{l}\text { Teluk Bakau, } \\
\text { P.Trikora }\end{array}$ & 5 & 1 & 4 & 5 & 3 & 1 & 3,33 & sedang \\
\hline $\begin{array}{l}\text { Malang } \\
\begin{array}{l}\text { Rapat, P. } \\
\text { Alur Putih }\end{array}\end{array}$ & 5 & 1 & 4 & 5 & 3 & 1 & 3,33 & sedang \\
\hline $\begin{array}{l}\text { Kawal, } \\
\text { Muara } \\
\text { S.Kawal }\end{array}$ & 5 & 1 & 4 & 4 & 3 & 1 & 3,16 & sedang \\
\hline $\begin{array}{l}\text { Tanjung } \\
\text { Keling }\end{array}$ & 5 & 1 & 1 & 5 & 2 & 1 & 2,50 & rendah \\
\hline $\begin{array}{l}\text { Berakit, } \\
\text { P.Pangudang }\end{array}$ & 5 & 1 & 3 & 4 & 3 & 1 & 2,83 & rendah \\
\hline $\begin{array}{l}\text { Galang } \\
\text { Batang, } \\
\text { Muara Sungai }\end{array}$ & 5 & 1 & 1 & 4 & 2 & 1 & 2,30 & rendah \\
\hline
\end{tabular}

Keterangan: KP : Kemiringan Pantai, TG: Tinggi Gelombang, PS: Pasang Surut, TP: Tipe Pantai, AS: Abrasi Sedimentasi, AP: Arus Pantai

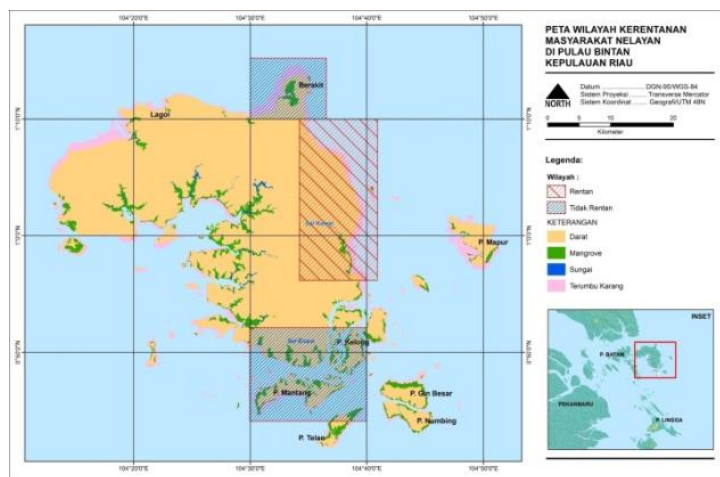

Gambar 7. Nilai Kerentanan fisik di daerah penelitian Pantai Bintan
Tabel 2. Kerentanan fisik di kawasan wisata berdasarkan parameter geomorfologi

\begin{tabular}{|l|l|l|l|l|l|}
\hline Lokasi & $\left({ }^{\circ}\right)$ & $\mathrm{d}(\mathrm{m})$ & $\%$ & $\begin{array}{l}\text { Skor } \\
\text { CVI }\end{array}$ & $\begin{array}{l}\text { Kategori } \\
\text { Kerentanan }\end{array}$ \\
\hline $\begin{array}{l}\text { Gunung } \\
\text { Kijang,Teluk } \\
\text { Bakau, } \\
\text { P.Trikora }\end{array}$ & 0.12 & 2.66 & $3-5$ & 5 & Sangat tinggi \\
\hline $\begin{array}{l}\text { G.Kijang, } \\
\text { Malang Rapat, } \\
\text { P. Alur Putih }\end{array}$ & 0.16 & 3.06 & $0-3$ & 5 & Sangat tinggi \\
\hline $\begin{array}{l}\text { Kawal, Muara } \\
\text { S.Kawal }\end{array}$ & 0.09 & 2.28 & $0-3$ & 5 & Sangat tinggi \\
\hline $\begin{array}{l}\text { Teluk Bintan, } \\
\text { Tanjung Keling }\end{array}$ & 0,05 & 2.10 & $0-3$ & 5 & Sangat tinggi \\
\hline $\begin{array}{l}\text { Berakit, } \\
\text { P.Pangudang }\end{array}$ & 0.18 & 3.1 & $0-3$ & 5 & Sangat tinggi \\
\hline $\begin{array}{l}\text { Galang Batang, } \\
\text { Muara Sungai }\end{array}$ & 0,09 & 2,3 & $0-3$ & 5 & Sangat tinggi \\
\hline $\begin{array}{l}\text { Galang Batang, } \\
\text { Pantai }\end{array}$ & 0,12 & 2 & $0-3$ & 5 & Sagat tinggi \\
\hline Rata-Rata & 0,115 & 2,58 & & 5 & Sangat tinggi \\
\hline
\end{tabular}

Tabel 3. Skor kerentanan fisik di kawasan perikanan

\begin{tabular}{|c|c|c|c|c|c|c|}
\hline \multirow[t]{2}{*}{ No. } & \multirow[t]{2}{*}{ Lokasi } & \multicolumn{5}{|c|}{ Kerentanan masya rakat nelayan } \\
\hline & & $\begin{array}{l}\text { Sangat Tinggi } \\
\text { (5) }\end{array}$ & $\begin{array}{l}\text { Tinggi } \\
\text { (4) }\end{array}$ & $\begin{array}{c}\text { Sedang } \\
\text { (3) }\end{array}$ & $\begin{array}{l}\text { Rendah } \\
\text { (2) }\end{array}$ & $\begin{array}{l}\text { Sangat rendah } \\
\text { (1) }\end{array}$ \\
\hline 1 & Desa Berakit & & $\mathrm{v}$ & & & \\
\hline 2 & Kawal & & v & & & \\
\hline 3 & Tanjung Keling & & & & $\mathrm{v}$ & \\
\hline 4 & Desa Dompa & & & & & $\mathrm{v}$ \\
\hline 5 & Batu Licin & & & & & v \\
\hline 6 & Alur Putih & & & & $\mathrm{v}$ & \\
\hline 7 & Galang Batang & & & & v & \\
\hline 8 & Pantai Trikora & & & & v & \\
\hline 9 & Malang Rapat & & & & v & \\
\hline 10 & Teluk bakau & & & & v & \\
\hline
\end{tabular}

Tabel 4. Dampak perubahan iklim terhadap sosial ekonomi di masyarakat pesisir

\begin{tabular}{lcccc}
\hline \multicolumn{1}{c}{ Sektor } & \multicolumn{4}{c}{ Dampak } \\
\cline { 2 - 5 } & $\begin{array}{c}\text { Frekuensi } \\
\text { Pangan }\end{array}$ & Erosi & Penggenangan & Intrusi Air Laut \\
Sumber daya air & & & $\sqrt{ }$ & $\sqrt{ }$ \\
Agrikultural & $\sqrt{ }$ & $\sqrt{ }$ & $\sqrt{ }$ \\
Kesehatan masyarakat & $\sqrt{ }$ & $\sqrt{ }$ & \\
Perikanan & $\sqrt{ }$ & $\sqrt{ }$ & $\sqrt{ }$ \\
Turisme & $\sqrt{ }$ & $\sqrt{ }$ & $\sqrt{ }$ \\
Pemukiman & $\sqrt{ }$ & $\sqrt{ }$ & $\sqrt{ }$ & $\sqrt{ }$ \\
\hline
\end{tabular}

Analisis tingkat kerentanan pantai dan pesisir mengacu pada metode CVI (Coastal Vunerability Indeks) dan SIDIK (Sistem Informasi data indeks kerentanan) berdasarkan bobot dan skor variable yang ditetapkan oleh USGS dan disesuaikan 
dengan area kajian. Hasil dari pembobotan skor diperoleh bahwa skor kerentanan lingkungan fisik kawasan wisata tergolong kategori rendah-sedang (Tabel 2). Faktor rentannya lebih dipengaruhi oleh faktor geomorfologi dan sifat fisik sedimen, sedangkan faktor oseanografi hanya berpengaruh besar pada puncak peralihan musim.

Kerentanan masyarakat pesisir tergolong rendah (skor 2) di kawasan wisata di sepanjang Pantai Timur Teluk Bakau danTtrikora sampai Lagoy. namun di kawasan perikanan tergolong tinggi (skor 4), yaitu di desa Kawal dan Berakit (Tabel 3). Tingginya kerentanan masyarakat pesisir di kawasan perikanan ini lebih dipengaruhi oleh faktor sosial dan budaya daripada faktor alam/iklim. Dampak dari tingginya kerentanaan masyarakat dan ditambah dengan tingginya kerentanan wilayah pesisir akan menurunkan kestabilan dan kualitas berbagai sektor seperti agricultural, perikanan dan permukiman yang akhirnya akan mempengaruhi ketahanan pangan (Tabel 4) Oleh karena itu, strategi adaptasi yang tepat adalah strategi akomodatif, dengan pertimbangan sumber daya alam masih mendukung dan berada di kawasan ekonomis, sehingga masyarakat tetap bisa beraktifitas dikawasan ini dengan lebih adaptif dalam memaksimalkan fungsi lahan .

\section{Strategi Adaptasi}

Ada dua kelompok nelayan yang terdapat di Pulau Bintan yaitu suku laut dan suku melayu darat, yang keduanya mempunyai daya kerentanan dalam menghadapi perubahan cuaca berbeda-beda. Nelayan suku laut umumnya lebih adaptif terhadap perubahan lingkungan karena mereka memeiliki keanekaragaman alat tangkap.Strategi yang diterapkan masyarakat nelayan yaitu memiliki alat tangkap yang banyak, seperti Jaring Udang, jaring belanak, belat, bubu ikan kerapu, jaring ketam bakau, jaring ketam rijungan, tombak, pancing rawai gulung, sehingga berubahnya cuaca dapat disiasati dengan keragaman pemilikan alat tangkap, dan berpindah lokasi penangkapan. Selain itu suku laut lebih memahami karakteristik lingkungan karena sering berpindah tempat/pemukiman tidak tetap, terbiasa bermigrasi ke tempat baru yang kondisi iklimnya lebih bersahabat. Berbeda dengan suku melayu yang hanya terbiasa dengan mono alat tangkap (bagan tancap atau apung), serta budaya menetap hanya di satu wilayah pemukiman saja, sehingga rentan terhadap perubahan iklim [10].

Beberapa strategi adaptasi untuk masyarakat nelayan terhadap kerentanan fisik pesisir yang dapat dilakukan adalah ategi protektif dan akomodatif.

1. Protektif (Untuk wilayah dengan kerentanan tinggi)

Misalnya pembuatan dam, tanggul, seawall, pemecah gelombang, pintu air, penahan pasut (tidal barrier), penahan intrusi airlaut, pembuatan sand dune, wetland, penghutanan, penanaman mangrove, dan pemeliharaan pantai berkala.

2. Akomodatif (Untuk kerentanan rendah sedang)

Hal ini dengan pertimbangan masyarakat tetap dapat melakukan aktifitas di kawasan pantai

Seperti pengalihan fungsi persawahan menjadi pertambakan dan pengalihan fungsi pemukiman menjadi rumah panggung

3. Mundur (Retreat)

Hal ini dilakukan dengan memundurkan kawasan pemukiman yang berada di dekat pantai ke dataran yang lebih tinggi. Selain itu, dapat juga hanya dengan memindahkan bangunan yang terancam saja. Hal lain yang dapat dilakukan dalam strategi retreat adalah dengan meniadakan bangunan di kawasan rentan dan membangun yang baru di kawasan yang stabil.

\section{KESIMPULAN}

Analisis tingkat kerentanan pantai dan pesisir mengacu pada metode CVI (Coastal Vunerability Indeks) dan SIDIK (Sistem Informasi data indeks kerentanan) berdasarkan bobot dan skor variable yang ditetapkan oleh USGS dan disesuaikan dengan area kajian. Hasil dari pembobotan skor diperoleh bahwa skor kerentanan lingkungan fisik kawasan wisata tergolong kategori rendah-sedang. Faktor rentannya lebih dipengaruhi oleh faktor geomorfologi 
dan sifat fisik sedimen, sedangkan faktor oseanografi hanya berpengaruh besar pada puncak peralihan musim.

Kerentanan masyarakat pesisir tergolong rendah (skor 2) di kawasan wisata di sepanjang Pantai Timur Teluk Bakau danTtrikora sampai Lagoy. namun di kawasan perikanan tergolong tinggi (skor 4), yaitu di desa Kawal dan Berakit. Tingginya kerentanan masyarakat pesisir di kawasan perikanan ini lebih dipengaruhi oleh faktor sosial dan budaya daripada faktor alam/iklim. Oleh karena itu, strategi adaptasi yang tepat adalah strategi akomodatif, dengan pertimbangan sumber daya alam masih mendukung dan berada di kawasan ekonomis, sehingga masyarakat tetap bisa beraktifitas dikawasan ini dengan lebih adaptif dalam memaksimalkan fungsi lahan.

\section{UCAPAN TERIMA KASIH}

Ucapan terimakasih kami berikan kepada Drs. Happy Supriyadi Msi dan Drs Sudiyono, serta seluruh tim survey penelitian dampak perubahan iklim Pusat Penelitian Oseanografi LIPI di Pulau Bintan atas kontribusi dalam pengolahan data dalam penulisan laporan ini.

\section{DAFTAR PUSTAKA}

[1] Aldrian, E, Susanto, R, D. 2003. Identification of Three Dominant Rainfall Region Within Indonesia And Their Relationship to Sea Surface Temperature. International Journal of Climatology. Wiley InterScience.

[2] Balica, S. F., N. G. Wright \& F. Vander Meulen. 2012. A flood vulnerability index for coastal cities and its use in assessing climate change impacts. Nat. Hazards. 64:73-105.

[3] LIPI, 2017. Kajian Dampak Perubahan Iklim terhadap Pulau Kecil:Kerentanan Masyarakat Pesisir dan Lingkungan Fisik Kawasan Wisata Bahari Pulau Bintan. Laporan Pnelitian Pusat Penelitian Oseanografi 2017.

[4] Suhana, M.P., Nurjaya, I.W., Metta, N \& N. Natih, 2016. Analisis Kerentanan
Pantai Timur Pulau Bintan, Provinsi Kepulauan Riau menggunakan digital Shoreline Analysis System dan Metode Coastal Vulnerablity Index. Jurnal Teknologi Perikanan dan Kelautan IPB (6) $1: 21-38$.

[5] Emiyati, 2016. Analisis multitemporal sebaran suhu permukaan laut di perairan Bintan menggunakan data penginderaan jauh MODISdalamSupriyadi, I.H., R. Rositasari, M.Y. Iswari, 2016. Dampak perubahan penggunaan lahan terhadap kondisi padang lamun di perairan Timur Pulau Bintan Kepulauan Riau Makara Journal of Science, UI-Jakarta.

[6] Kumar TS, Nahendra RS, Nayak S, Radhakrishnan K, Suhu KC. 2010. Coastal vulnerability assessment for Orissa State, east coast of India. Coast Res. 26 (3): 523-534.

[7] Kaiser G. 2007. Coastal vulnerability to climate change and natural hazards. Forum DKKV/CEDIM: Disaster Reduction in Climate Change. Karlsruhe University.

[8] Gornitz VM. 1991. Global coastal hazards from future sea level rise. Palaeogeography, Palaeoclimatology, Palaeoecology (Global and Planetary Change Section). 89: 379-398.

[9] Hammar-Klose ES, Pendleton EA, Thieler ER, Williams SJ. 2003. Coastal Vulnerability Assessment of Cape Cod National Seashore (CACO) to SeaLevel Rise. USGS Report: 02-233.

[10] Fuad, 2018. Adaptasi Perubahan Iklim Dan Kerentanan Di Sektor Perikanan Tangkap Di Jawa Timur. makalah dalam lokakarya VA Jatim, Februari 2017 in USAID, 2018. Assessing Climate Change Adaptation in Indonesia: A review of Climate Vulnerability Assessment. 